\title{
UMA HISTÓRIA ESCRITA A QUATRO MÃOS
}

\author{
Renata Cardoso Belleboni Rodrigues ${ }^{1}$
}

1993. Aguardando o resultado do vestibular para ingresso no curso de História da Unesp, campus de Franca. Antes mesmo de ter ciência do resultado, já pensava em um mestrado em Grécia Antiga, ainda sem saber ao certo o que era uma pós-graduação. Novembro de 1996, tudo preparado para a defesa de meu TCC orientado de forma pacienciosa e muito competente pela professora Dra. Margarida Maria de Carvalho. No texto, a defesa de que a tragédia era o espelho da sociedade grega. Não um reflexo perfeito, mas muito próximo da realidade. Os apontamentos e ajustes que foram feitos pela banca me alertaram sobre o conceito de reflexo e incitaram o desejo de entender aquele de representação, além de me apresentar uma teoria historiográfica que me cativou. A forma e a extensão que o termo cultura ganhou durante a arguição me fizeram crer que aquele era o caminho a ser percorrido em possíveis pesquisas futuras. Percebi que seria um caminho árduo, pois trazia marcas de uma historiografia marxista ou mais sociológica dos professores que ministraram as disciplinas da graduação. A única certeza: tinha muito que aprender.

1997 foi um divisor de águas. Minha orientadora ao encaminhar meu texto e uma carta de apresentação a um dos autores que eu mais admirava, o professor Pedro Paulo Abreu Funari, me alertou: "ele é rápido na resposta". Quatro meses depois e nenhum retorno. Tinha a certeza de que meu texto não havia proporcionado uma boa leitura. Mas eis que a resposta chega e no envelope vários carimbos da França. A correspondência tinha sido desviada, cruzou duas vezes o oceano Atlântico antes de chegar a Franca. No texto havia apontamentos, correções, indicações de leitura. Em um papel à parte, uma primeira reunião agendada para 14 de julho às 11 h no IFCH. Dia e hora marcados, eu aguardava aquela conversa, ansiosa, talvez a mesma sensação de um garoto que vai conhecer seu ídolo do futebol. Às 11h03min o professor se apresenta e se desculpa pelo atraso. Atraso? Já neste primeiro encontro percebi a seriedade do que viria pela frente caso ele aceitasse me orientar. Uma hora e meia depois, saí de sua sala com uma proposta de pesquisa

\footnotetext{
1 Professora Doutora, Fundação Municipal de Ensino Superior de Bragança Paulista, Bragança Paulista, Brasil. E-mail: re.medusa@gmail.com
} 
bem diferente da que imaginava. Minha intenção era continuar a estudar o teatro grego, porém, iniciaria a leitura das obras de Jean-Pierre Vernant com o intuito de conhecer, entender e divulgar suas proposições, sua representação da Grécia Antiga. Em um primeiro momento, acreditei que seria fácil... desde quando entender a obra de um autor é fácil? Dois pensamentos se conflitavam a cada página lida: ou meu futuro orientador estava me testando ou acreditou em mim o suficiente para me repassar tal tarefa, quase uma façanha. A cada troca de cartas, quando eu enviava meus fichamentos e tentativas de texto, novas leituras sugeridas, questionamentos colocados, correções (mesmo ortográficas) realizadas. Eu nem havia ainda definido exatamente o que abordaria no projeto que apenas seria apresentado ao final de 1999 e as orientações avançavam.

Outubro de 1997. Em um Congresso da SBEC realizado na USP um novo encontro. Desinteressadamente e, com certo constrangimento, levei um pré-projeto esboçado. Modelo esse que o próprio professor havia passado, e, qual não foi minha surpresa: ao final da leitura, sugestões mudanças aqui e ali e o prazo para apresentação do projeto caiu para um mês. Novembro, inscrição. Março de 1998 aulas iniciadas e as primeiras orientações oficiais agendadas. Como eu, muitos ingressantes eufóricos com a nova realidade. Muitos como eu, filhos de instituições do Estado e mesmo do país, aguardando a hora em que a biblioteca do IFCH se tornaria nossa segunda morada. Muitos como eu, apresentados a um grupo de docentes defensores de uma história cultural. Durantes as aulas do professor Funari e no decorrer das orientações o que antes era novidade se tornou tão natural que me parecia (e ainda parece) que não há outra forma de ver a história. Mas uma lição sempre esteve presente: é preciso conhecer e buscar entender as demais correntes historiográficas e mesmo filosóficas, arqueológicas, sociológicas, pois, para criticar é preciso ter embasamento, para entender a história é preciso aceitar que ela não está sozinha na empreitada de compreensão da cultura humana. Esse aprendizado e o impulso para mais e mais leituras devo a meu orientador.

Por três anos foram muitas aulas, seminários, congressos fora e dentro da Unicamp, novos autores para ler, para conhecer pessoalmente, tantos conceitos a compreender. Mas também muitos cafés, um vinho de vez em quando, almoços com a turma toda, muita conversa e risada. A cada dia o laço de amizade se estreitava e eu nem imaginava o quão necessário ele se tornaria logo mais à frente. Com a qualificação marcada e texto entregue à banca, uma última conversa e um conselho: "fique calma, acompanhei o processo, você escreveu o texto, conhece as entrelinhas, a 
banca é amiga e eu me colocarei se necessário". E não é que deu certo? Estava calma para este momento de correções, sugestões e críticas. E qual não foi minha surpresa quando questionamentos severos foram colocados pelo primeiro arguidor. Críticas à escrita, ao formato, à proposta e mesmo ao resultado até ali apresentado. Mas eu estava calma, afinal, meu orientador estava ali, atento, anotando cada palavra pronunciada. Foi quando o segundo argüidor bateu com a mão na mesa e disse: "como assim, entrevistou Vernant, seu próprio objeto de estudo e não contou a saga aqui? Quero saber de tudo". Foi um momento de alívio em meio à tensão. Novos apontamentos e contribuições. Ao final, tive o enorme prazer em ouvir Pedro Paulo Abreu Funari se posicionar em minha defesa. Esclareceu ponto a ponto todos os questionamentos realizados. Promessa feita, promessa cumprida.

Qualificação encerrada e, como de costume, um cafezinho para novas orientações rumo à defesa. Falamos um pouco sobre as fortes críticas e sobre as sugestões. Mal sabia sobre os desdobramentos de minha qualificação. Todos os presentes se assustaram com as primeiras colocações, pela forma que foram feitas e pelo tom dispensado a elas. Uma colega quase desistiu de sua própria qualificação marcada para poucos dias. Enquanto as coisas esquentavam para o lado de meu orientador, eu seguia rumo à casa de meus país no interior do Estado. No caminho, a dúvida se eu realmente havia satisfeito os membros da banca e ao mesmo tempo tranquila com as palavras finais de Funari. Mal cheguei a Ribeirão Preto, casa de meu namorado, meus pais me telefonam avisando que o professor queria falar comigo. Minutos depois, palavras afáveis me deram a certeza de que eu tinha não apenas um orientador, mas um amigo ao lado. Conforme ouvia suas palavras, anotava-as em um papelzinho sobre a mesa. Ainda guardo comigo esta recordação.

No doutorado não foi diferente. Agora aprendia com Funari como ler imagens. Medusa se transformava a cada autor descoberto e a cada consideração nas orientações. A pesquisa ganhava forma e as peças se encaixavam num quebra-cabeça mitológico, simbólico, cultural. Muitas vezes senti a dúvida do caminho tomado... inúmeras vezes fui redirecionada ao caminho certo pelas mãos amigas daquele que me mostrou o quanto a história é complexa e fascinante.

Foi durante este percurso que decisões difíceis foram tomadas. Como havia sido contemplada com uma bolsa da Fapesp durante o mestrado, a tentaria novamente ou aceitaria a proposta de assumir a coordenação do curso de História da Faculdade de Ciências e Letras de Bragança Paulista 
onde estou há 18 anos ministrando História Antiga? Seus conselhos foram preciosos: "pense na carreira", "pesquisa, docência e administração podem caminhar juntas", "pense nas contribuições que poderá repassar aos colegas e alunos". A coordenação aceita, a pesquisa teve seu andamento, a docência se aprimorou. Bons conselhos geraram bons resultados.

Amigo que é amigo convida outros amigos para qualificação e defesa. Como foi bom ter colegas de mestrado e doutorado em minha banca. Fácil, não? Assim como eu, também aprenderam com o mestre. Sabiam o que e como cobrar. Outro presente recebido foi a presença de minha primeira orientadora à mesa. Ao final de tudo, a promessa do mestrado foi renovada: novamente palavras em minha defesa foram pronunciadas. Também as guardo com carinho. A história não terminou aí. Tive o prazer de fazer parte de bancas de novos orientandos do professor. Seja como suplente ou como membro, revivi nas páginas lidas as orientações recebidas tantas vezes. É possível reconhecer as suas marcas em textos tão distintos.

Para finalizar, só tenho a reafirmar que sou a pesquisadora que sou porque tive um exemplo. Sou a docente que sou porque tive um exemplo. Posso mesmo dizer que a pessoa que me tornei é resultado desse mesmo exemplo. Caro amigo Pedro Paulo, muito obrigada pelos ensinamentos, pelas defesas, pela amizade, por estas páginas da história escritas a quatro mãos. 